\title{
Mixed Germ Cell-Sex Cord-Stromal Tumor
}

National Cancer Institute

\section{Source}

National Cancer Institute. Mixed Germ Cell-Sex Cord-Stromal Tumor. NCI Thesaurus. Code C5241.

A biphasic neoplasm that arises from the ovary or the testis. It is characterized by the presence of neoplastic germ cells and neoplastic sex cord-stromal cells. It includes the gonadoblastoma and mixed germ cell-sex cord stromal tumor, unclassifiable. 